\title{
ABUNDANCE AND DIVERSITY OF ZOOPLANKTON IN LEMBEH STRAIT, BITUNG, INDONESIA
}

\author{
Inneke F.M. Rumengan, ${ }^{1)}$, J. Akerina ${ }^{2)}$, M.M.F. Rampengan ${ }^{3)}$, and K.W.A. Masengi ${ }^{1}$ \\ ${ }^{1)}$ Faculty of Fishery and Marine Science, Sam Ratulangi University, Manado, Indonesia \\ ${ }^{2)}$ Graduate School of Sam Ratulangi University, Bahu, Manado \\ ${ }^{33}$ Faculty of Mathematics and Natural Sciences, Nas. Univ. Manado, Tondano \\ E-mail: inneke0511@gmail.com
}

Received: September 2010

Accepted: February 2011

\begin{abstract}
This study examined the diversity and abundance of zooplankton in Lembeh Strait, North Sulawesi. Plankton were sampled monthly from September 2004 to February 2005, collected at four stations using a plankton net of $300 \mu \mathrm{m}$ meshsize with vertical tow of $10 \mathrm{~m}$ water column from the bottom. Environmental factors i.e pH, salinity, current velocity, and dissolved oxygen (DO) were measured in situ at the time of plankton sampling. In general, the environmental conditions of Lembeh Strait were in optimal range for zooplankton. There was a similar pattern in the abundance of zooplankton among stations. Crustacea (mainly Copepoda) was the dominant genera among stations, followed by Ciliata and Tunicata. In all stations, the most abundance taxa (72.3\%) was Crustacea (21 genera), mainly copepod (18 genera). There were 7 other classes of holoplankton: Ciliata (2 genera), Rhisopoda (1 genus), Hidrozoa (1 genus), Polychaeta ( 2 genera), Sagitoedea (1 genus) and Tunicata ( 2 genera). Meroplankton (larva) were only represented by 5 genera. The most common genera were calanoid copepods, such as Calanus spp., Undinula spp., Eucalanus spp., Rhincalanus spp., Paracalanus spp., and Acartia spp. Diversity, evenness and dominance indices showed that Serena Island, a relatively uncontaminated area, was more productive than the other three stations which were considered as relatively contaminated area with anthrophogenic sources.
\end{abstract}

Keywords: abundance, diversity, zooplankton, Lembeh Strait, North Sulawesi

\section{INTRODUCTION}

Understanding the magnitude of marine ecosystems to achieve sustainable exploitation and keep their role in biological, chemical and physical dynamics represents a real challenge for ecological situations. It is clear that anthropogenic influences are increasing significantly in the global marine environment, primarily on coastal areas. Given the importance of habitat and marine organisms, it is important to have biological measurement of marine environments, particularly in areas that have significant anthropogenic perturbations, such as harbor areas (Rumengan et al., 2008).

Zooplankton communities are remarkable important in the coastal ecosystems since they play an important role in the functioning of marine ecosystems and in biogeochemical cycles
(Roemmich and McGowen, 1995). In fact, their abundance can show considerable variability which provides information about the dynamics of their natural populations. Information on plankton diversity at a regional scale is known essential for understanding its fluctuation as well as for ecosystem management. Its information is important because the science of biodiversity itself has primarily focused on the global features (Beaugrand et al., 2000).

Lembeh Strait in Bitung, North Sulawesi, Indonesia brings water mass from Malucca Sea and Sulawesi Sea, and therefore become migratory area for fish, and containing enormous abundance of plankton which support the life of surrounding marine biota (Tackett and Tackett, 1996). The increasing industrialization of Bitung has led to threat to the existing biodiversity of plankton and 
other increased shipping traffic and industrial activities may be a source of environmental disturbance for organisms in this area.

Many researches have shown that plankton may be used as an indicator of environmental changes (Beaugrand et al., 2000, Taylor, 2002). In Lembeh Strait, there is little information on the biodiversity of plankton, therefore the need of plankton data as "a baseline data" is important and essential to drive the development activities in Bitung to the environmental friendly approach. Here we summarize the diversity of zooplankton in the Lembeh Strait based on descriptive approach over a period of six month between September 2004 and February 2005.

\section{MATERIALS AND METHODS}

This study was conducted in Lembeh Strait, Bitung, North Sulawesi-Indonesia (Figure 1). Lembeh Strait is located between Bitung Harbour and shipyard area and Lembeh Island, with $16 \mathrm{~km}$ length, 1-2 km width, and 25-70 m depth, between geographical positions of $1^{\circ} 24^{\prime} 0^{\prime \prime}-1^{\circ} 36^{\prime} 0^{\prime \prime} \mathrm{N}$ and $125^{\circ} 06^{\prime} 0^{\prime \prime}-125^{\circ} 06^{\prime} 0$ " $\mathrm{E}$. There were four sampling stations: St 1 (Bitung harbors, Naval base, ferry port, shipyard and surrounded by urban settlement), St 2 (Serena Island, in the middle of Lembeh Strait, in front of Serena Island, unpopu- lated island, location of recreational activities), $\mathrm{St}$ 3 (nearby Lembeh Island, in front of Kelapa Dua shipyard), and St 4 (nearby Girian beach, coconut oil industry, and fish processing). The position of sampling stations was determined using GPS (Global Positioning System).

Sample collections were conducted monthly from September 2004 to February 2005. Plankton samples were vertically collected along $10 \mathrm{~m}$ of water column using plankton net of $30 \mathrm{~cm}$ in diameter $300 \mu \mathrm{m}$ of mesh size and sampling were in preserved $4 \%$ formaldehyde. In each station, physical parameters such as current velocity, temperature and salinity were measured in situ along with collecting water samples for chemical measurement including $\mathrm{pH}$ and $\mathrm{DO}$ (dissolved oxygen).

Zooplankton were examined under a compound microscope with $400 \mathrm{x}$ magnification, and identified following some manuals of Newell and Newell (1963), and Yamaji (1982) in Laboratory of Marine Biotechnology, Faculty of Fisheries and Marine Science, Sam Ratulangi University. As described by Rumengan (2006), the abundance of zooplankton $(\mathrm{N})$ is normally determined by dividing the individual number in each sample (n) by the filtered seawater Volumn $(V)$, where $V=\pi r^{2}$ $\mathrm{D}$ ( $\mathrm{r}$ is radius of plankton net mouth opening, and

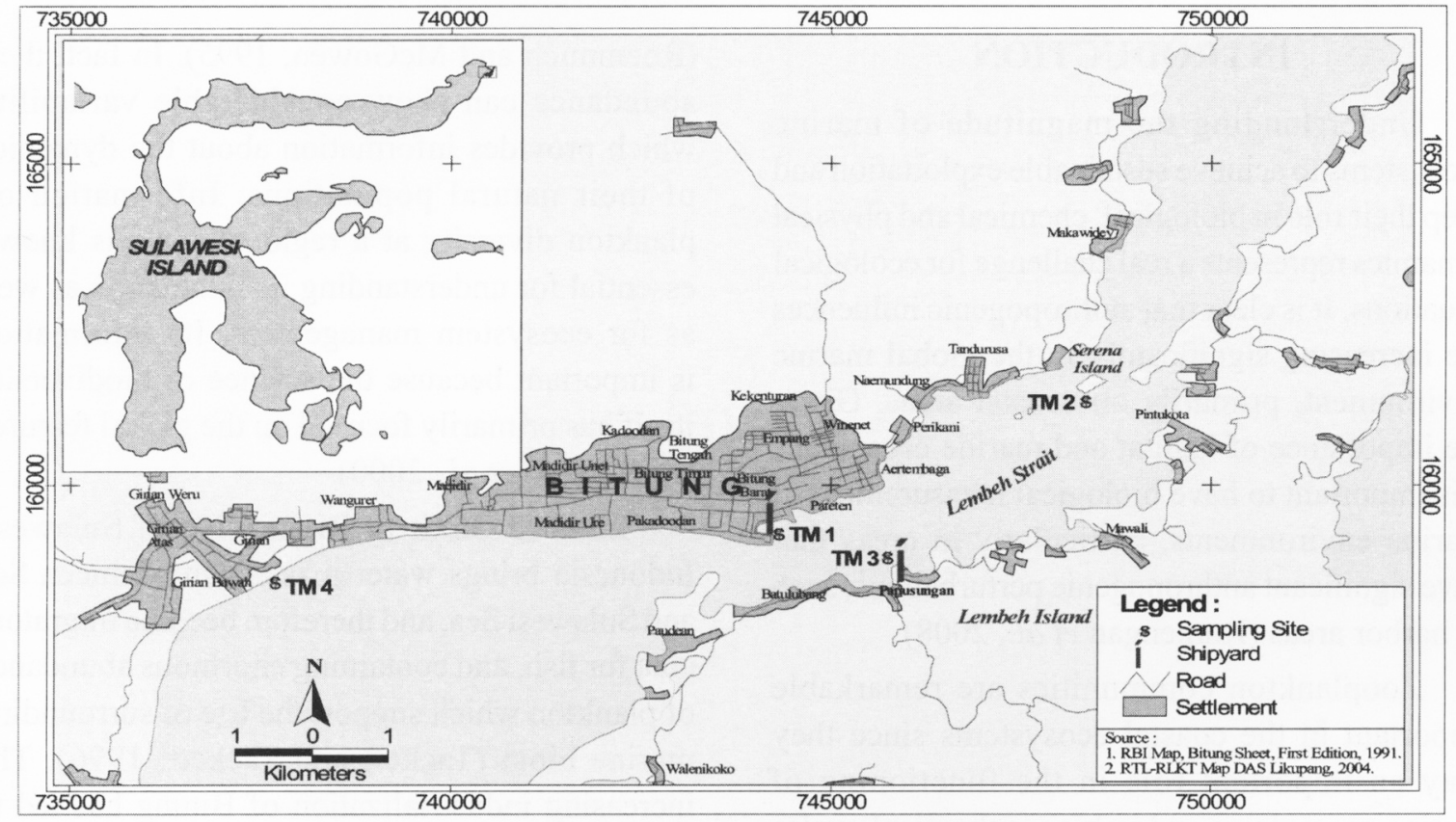

Figure 1. Sampling stations of the present study. 
$\mathrm{D}$ is depth of net towing, which was about $10 \mathrm{~m}$ in this study). Based on the composition and density of plankton, an index of diversity was determined using the Shannon-Wiener formula (Parsons et al., 1984). Evenness and Dominance Indices were determined as explained by Lind (1979) and Odum (1971) respectively.

\section{RESULTS AND DISCUSSION}

It was clear that the condition of temperature and salinity along Lembeh Strait tended to be constant and normal for coastal area through sampling stations (Table 1). The similarity of temperature range among stations can be explained as the consequences of consistent sampling time. The salinity range of 30-33\% showed that water mass in Lembeh strait was the mixing of coastal and ocean waters. Moreover, $\mathrm{pH}$ in all stations ranged from $8.00-8.40$, indicating that the water tended to be alkaline. The range of dissolved oxygen concentrations of $2.60-4.97$ ppm showed the variation within 4 sampling stations. The site that closed to the industrial activities and urban settlement had the lowest DO since these activities produced wastes that could contain bacteria which required oxygen for respiration. Variation in cur- rent velocity in all stations indicated the different water mass condition.

The water mass in Lembeh Strait with a relatively strong current provided a favorable condition for zooplankton to grow. This was consistent with the findings of Coyle and Pinchuk (2003) that strong currents together with the characteristic of mixing water provide relative abundance of most zooplankton taxa. Both current velocity and zooplankton abundance in Serena Island (St 2) were higher than in the other stations.

It was likely that the number of taxa was relatively consistent among stations, but the abundance increased through sampling periods for all stations (Figure 2). The high abundance of zooplankton on January and February 2005 could be argued as a result from the high level of rainy season that brought high nutrient level. The abundance of zooplankton was generally greater at all stations except at Bitung Harbor (St 1) (Figure 2). Moreover, the greatest abundance of zooplankton was in the Serena Island. This phenomenon could be explained as the consequences of its location located inside the strait that is far from the industrial and urban activities (unpopulated island). Similar tendency was reported by Rawlinson et al.(2005) that greater density of plankton was discovered
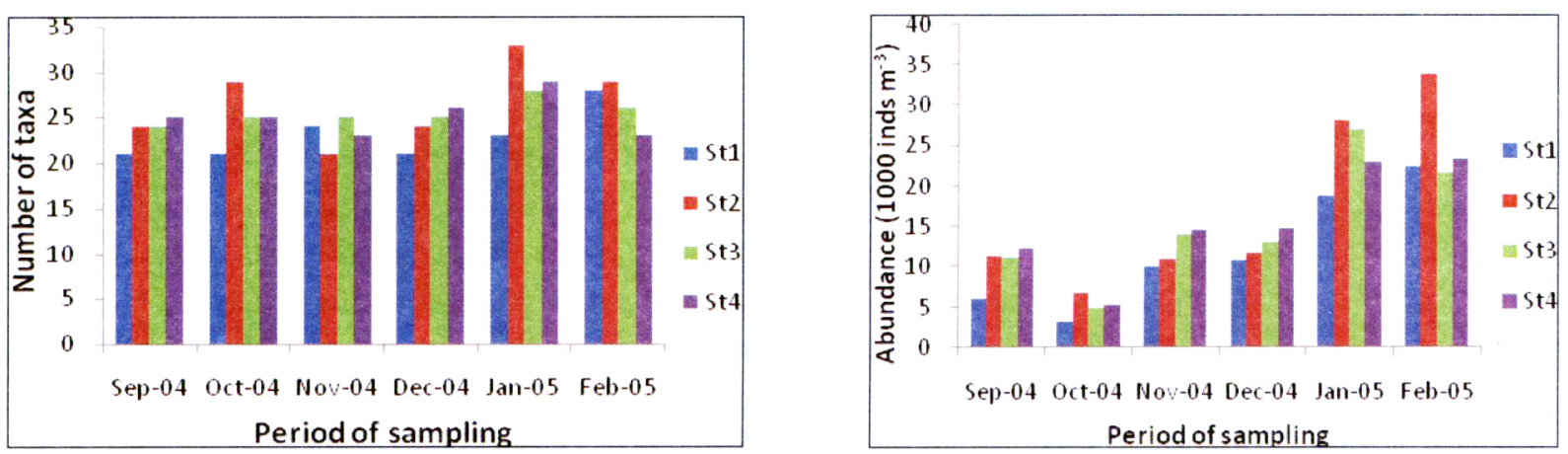

Figure 2. Number of taxa and abundance of zooplankton in Lembeh Strait during September 2004 to Februari 2005

Table 1. Some Environmental Factors of Lembeh Strait, North Sulawesi

\begin{tabular}{|c|c|c|c|c|}
\hline \multirow{2}{*}{ Parameters } & \multicolumn{4}{|c|}{ Stations } \\
\cline { 2 - 5 } & St 1 & St 2 & St 3 & St 4 \\
\hline Temperature (oC) & $25-28$ & $25-28$ & $26-28$ & $27-28$ \\
\hline Salinity (psu) & $30-32$ & $30-32$ & $30-33$ & $30-32$ \\
\hline Current Velocity (cm sec-1) & $10.35-23$ & $12.4-25.22$ & $10.37-23.56$ & $11.22-23.65$ \\
\hline pH & $8.00-8.30$ & $8.00-8.21$ & $8.00-8.40$ & $8.00-8.30$ \\
\hline DO (ppm) & $2.60-4.76$ & $3.80 v 4.97$ & $3.78-4.95$ & $3.64-4.95$ \\
\hline
\end{tabular}


inside rather than outside of the bay in the south west coast of Ireland.

The present findings were much higher than the abundance of zooplankton collected with similar plankton net $(300 \mu \mathrm{m})$ and vertical towing in other Indonesian waters, such as in Togian waters (Central Sulawesi) in June 1995 which was in range of 50-485 ind. $\mathrm{m}^{-3}$. However, in the same location, Togian waters, sample collection with the smaller plankton net $(80 \mu \mathrm{m})$, in May-June 1995 , the abundance was reported much higher, ranging from 406 to 37,308 ind. $\mathrm{m}^{-3}$ (Arinardi et al., 1996).

As shown in Figure 3, among 5 phyla, Arthoropoda were the most numerous (66.4-72.3 $\%)$ as well as diverse in terms of genus composition. Within this phylum 21 genera were identified; 18 genera of them were copepods. This was consistent with the common findings worldwide that copepods dominate up to $70 \%$ in most tropical coastal waters (Rumengan et al., 2009). The most common genera were calanoid copepods, such as Calanus spp., Undinula spp., Eucalanus spp., Rhincalanus spp., Paracalanus spp., and Acartia spp. Therefore, the principal taxa of zooplankton in Lembeh Strait were copepods.
The other zooplankton were of varying importance and consisted of Ciliata (2 genera), Rhisopoda (1 genus), Hidrozoa (1 genus), Polychaeta ( 2 genera), Sagitoedea (1 genus), and Tunicata ( 2 genera). The other taxa were 5 genera of meroplankton. In general, meroplankton consisted of larval stages of benthic invertebrates belonging to Echinodermata, Mollusca, Crustacea and Polychaeta (Arinardi et al., 1996). The abiotic factors as shown in Table 1 were more likely supporting the occurrence of meroplankton, but it remains for future study to characterize specific larval development and physical and chemicals properties of the environment in Lembeh Strait.

In general the environmental condition of Lembeh strait during sampling period was still in optimal range for zooplankton (Table 2). Diversity index based on Shannon-Wiener (bits) ranged from 2.71 to 3.02 , the lowest one was at Girian (St 4), and the highest was at Serena Island (St 2). Moreover, Evenness and Dominance Indices were in the same trend as for Diversity Index which showed that Serena Island was the most productive water among the four stations. Diversity Index confirmed that the zooplankton diversity in Lembeh Strait

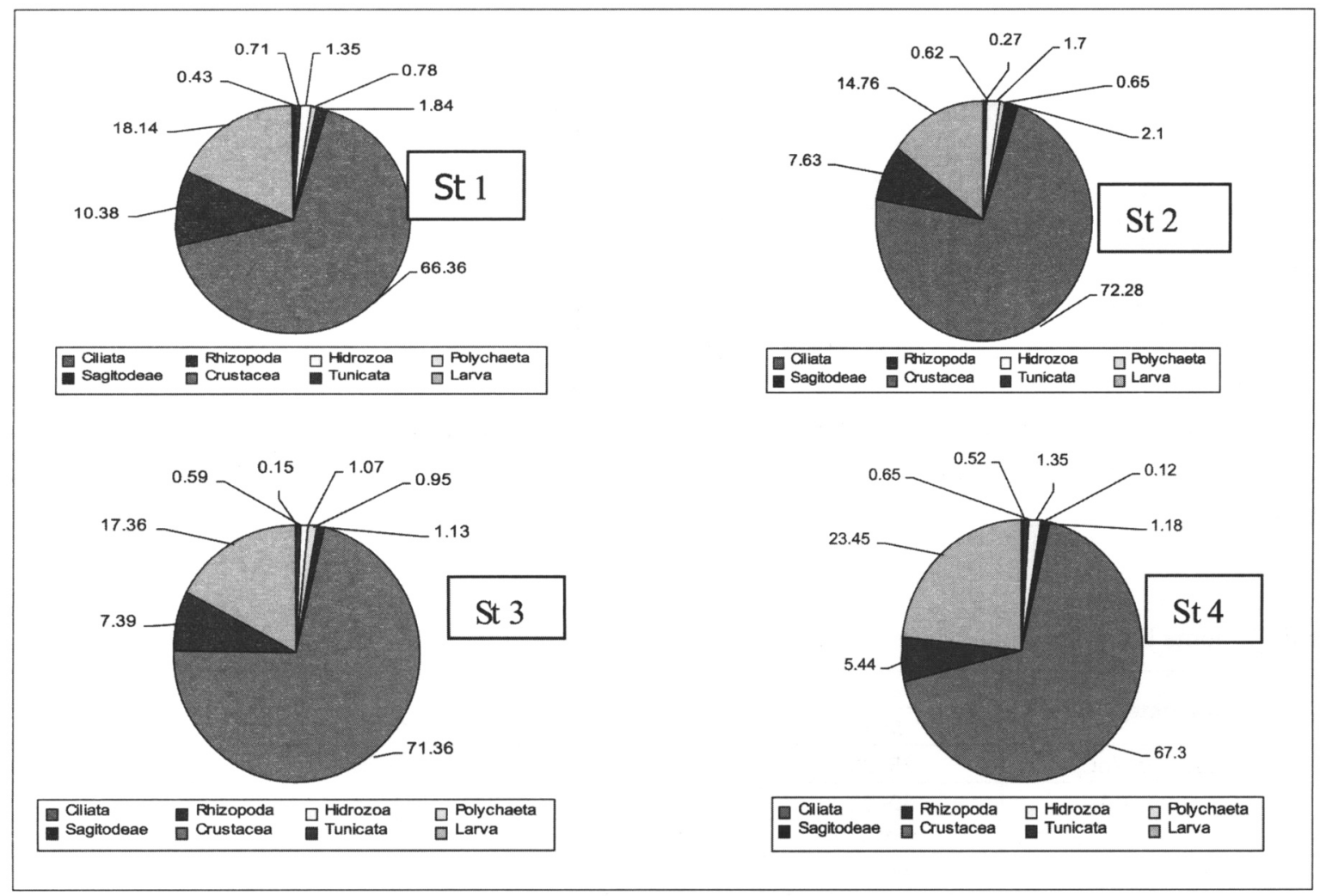

Figure 3. Taxa composition of each sampling site in Lembeh Strait 
Table 2. Index of Diversity, Evenness and Dominance of Zooplankton in Lembeh Strait

\begin{tabular}{|c|c|c|c|}
\hline Station & Diversity Index & Eveness Index & Dominance Index \\
\hline St 1 & $2.71-2.81$ & $0.59-0.89$ & $0.064-0.089$ \\
\hline St 2 & $2.71-3.02$ & $0.56-0.95$ & $0.062-0.087$ \\
\hline St 3 & $2.71-2.82$ & $0.54-0.89$ & $0.069-0.90$ \\
\hline St 4 & $2.71-2.92$ & $0.53-0.91$ & $0.072-0.121$ \\
\hline
\end{tabular}

was moderate (Diversity Index 1-3) based on the classification from Strin (1981). He argued that its value (moderate) signing that the abundance of marine biota in that area can simply be changed by a hazardous contamination. One of possible reasons for this is Lembeh Strait has a harbor area that has been found contaminated with tributyltin compounds in sediments (Rumengan et al., 2008).

More extensive studies concerning zooplankton are required to understand plankton biodiversity as a whole especially on the geographical and spatial distribution to describe population and community dynamics in Lembeh Strait, regarding with anthropogenic input into coastal water. As zooplankton plays an important role in marine food chain as primary food for the higher animal taxa, any adverse effects of pollutants on this zooplankton may lead to serious ecological consequences (Rumengan and Ohji, 2009; Rumengan et al., 2009).

\section{ACKNOWLEDGEMENT}

We thank to the Plankton Group of the Japan Society for the Promotion of Sceince (JSPS) Multilateral Program with core university, University of Tokyo, especially, Prof. S. Nishida of the Atmospheric and Ocean Research Institute for the encouragements and valuable corrections.

\section{REFERENCES}

Arinardi, O.H., Trimaningsih, S.H. Riyono, and E. Asnaryanti. 1996. The Range of Abundance and Predominant Plankton Composition in Central Indonesian Waters (In Indonesian). Jakarta: P2O LIPI, 94 pp.

Beaugrand, G., F. Ibanez, and P.C. Reid. 2000. LongTerm and Seasonal Fluctuations of Plankton in Relation to Hydroclimatic Features in the English Channel, Celtic Sea, and Bay of Biscay. Mar. Ecol. Prog.Ser., 200: 93-102.
Coyle, K.O. and A. Pinchuk. 2003. Annual Cycle of Zooplankton Abundance, Biomass and Production on the Northern Gulf of Alaska Shelf, October 1997 through October 2000. Fish. Oceanogr., 12:4/5: 327-338.

Lind, O.T. 1979. Handbook of common methods in limnology. CV Mosby Company-St.Louis.

Newell, G.E. and R.C. Newell. 1963. Marine plankton: practical guide. Hutchinson Educational LTD 178-202 Great Portland St. London

Odum, E.P. 1971. Fundamentals of Ecology. W.B. Saunders Co. Philadelphia.

Parsons, T.R., M. Takahashi, and B. Hagrave. 1984. Biological oceanography process. Third Edition. New York: Pergamon Press.

Rawlinson, K.A., J. Davenport, and D.K.A. Barnes. 2005. Tidal Exchange of Zooplankton between Lough Hyne and the Adjacent Coast. Estuarine, Coastal and Shelf Science, 62: 205-215.

Roemmich, D. and J. McGowan. 1995. Climatic Warming and the Decline of Zooplankton in the California Current. Science, 267: 1324-1326.

Rumengan, I.F.M. 2006. Planktonology. Teaching Material. Marine Science Study Program, Faculty of Fisheries and Marine Science, Sam Ratulangi University. Manado. pp.77.

Rumengan, I.F.M., M.Ohji, T.Arai, H.Harino, Z. Arifin, and N. Miyazaki. 2008. Contamination Status of Butyltin Compounds in Indonesian Coastal Waters: A Review. Coastal Marine Science 32 (1): 116-126.

Rumengan, I.F.M. and M. Ohji. 2009. Plankton (Chapter 15, p 253-270). In: Ecotoxicology of Antifouling Biocides (Eds. T. Arai, H. Harino, M. Ohji and W.J. Langston). Springer. Library Congress Control Number 2008938544.

Rumengan, I.F.M., N.D. Rumampuk, D., Sumilat, and J. Rimper. 2009. The Life Cycle and Sensitivity of the Local Copepod, Apocyclops sp. to Tributyltin Exposure. Biota 14 (2): 125-129.

Strin, J. 1981. Manual Methods in aAquatic Environment Research. Part 8. Ecological Assessment of Poliutant Effects. FAO. Rome. 70p.

Tackett, L.P. and D.N. Tackett. 1996. Everything but Dragons in the King of Fire. In Garuda. p15-17. 
Taylor, A.H. 2002. "Extraction of a Weak Climatic Signal by Anecosystem". Nature, 416, 629-632
Yamaji, I. 1982. Illustration of the marine plankton of Japan. Japan: Houkusha Publishing Co. Ltd. 13-17. Osaka. 540. 